\title{
Efficacy of revefenacin, a long-acting muscarinic antagonist for nebulized therapy, in patients with markers of more severe COPD: a post hoc subgroup analysis
}

James F. Donohue

UNC School of Medicine

Edward Kerwin

Clinical Research Institute of Southern Oregon, LLC

Chris N. Barnes

Theravance Biopharma

Edmund J. Moran

Theravance Biopharma

\section{Brett Haumann}

Theravance Biopharma

Glenn D. Crater ( $\triangle$ Grater@theravance.com )

Theravance Biopharma

\section{Research article}

Keywords: COPD, efficacy, long-acting muscarinic antagonist, nebulized therapy, revefenacin.

Posted Date: April 14th, 2020

DOI: https://doi.org/10.21203/rs.3.rs-15871/v3

License: (c) This work is licensed under a Creative Commons Attribution 4.0 International License. Read Full License

Version of Record: A version of this preprint was published at BMC Pulmonary Medicine on May 11th, 2020. See the published version at https://doi.org/10.1186/s12890-020-1156-4. 


\section{Abstract}

Background: Revefenacin, a once-daily, long-acting muscarinic antagonist delivered via standard jet nebulizer, increased trough forced expiratory volume in 1 second $\left(\mathrm{FEV}_{1}\right)$ in patients with moderate to very severe chronic obstructive pulmonary disease (COPD) in prior phase 3 trials. We evaluated the efficacy of revefenacin in patients with markers of more severe COPD.

Methods: A post hoc subgroup analysis of two replicate, randomized, phase 3 trials was conducted over 12 weeks. Endpoints included least squares change from baseline in trough FEV 1 , St. George's Respiratory Questionnaire (SGRQ) responders, and transition dyspnea index (TDI) responders at Day 85. This analysis included patient subgroups at high risk for COPD exacerbations and compared patients who received revefenacin $175 \mu \mathrm{g}$ and placebo: severe and very severe airflow limitation (percent predicted $\mathrm{FEV}_{1} 30 \%-<50 \%$ and $<30 \%$ ), 2011 Global Initiative for Chronic Obstructive Lung Disease (GOLD) D, reversibility ( $\geq 12 \%$ and $\geq 200 \mathrm{~mL}$ increase in $\mathrm{FEV}_{1}$ ) to short-acting bronchodilators, concurrent use of long-acting $\beta$ agonists and/or inhaled corticosteroids, older age ( $>65$ and $>75$ years), and comorbidity risk factors.

Results: Revefenacin demonstrated significant improvements in $\mathrm{FEV}_{1}$ versus placebo at Day 85 among the intention-totreat (ITT) population and all subgroups. Additionally, there was a greater number of SGRQ and TDI responders in the ITT population and the majority of subgroups analyzed among patients who received revefenacin versus placebo. For the SGRQ responders, the odds of response (odds ratio $>2.0$ ) were significantly greater in the revefenacin arm versus the placebo arm among the severe airflow obstruction, very severe airflow obstruction and 2011 GOLD D subgroups. For the TDI responders, the odds of response (odds ratio $>2.0$ ) were significantly greater among the severe airflow obstruction subgroup and patients aged $>75$ years.

Conclusions: Revefenacin showed significantly greater improvements in $\mathrm{FEV}_{1}$ versus placebo in the ITT population and all subgroups. Furthermore, there were a greater number of SGRQ and TDI responders in the ITT population, and in the majority of patient subgroups among patients who received revefenacin versus placebo. Based on the data presented, revefenacin could be a therapeutic option among patients with markers of more severe COPD.

Trial registration: Clinical trials registered with www.clinicaltrials.gov (Studies 0126 [NCT02459080; 22 May 2015] and 0127 [NCT02512510; 28 July 2015]).

\section{Background}

Inhaled drug delivery is the foundation of chronic obstructive pulmonary disease (COPD) pharmacological treatment [1]. The most common devices used to administer aerosolized medication in day-to-day respiratory practice are the pressurized metered-dose inhaler (MDIs) and dry powder inhaler (DPIs) [2]. The ability to use these inhalers adequately may become problematic among patients with COPD whose disease and symptoms become more severe. For pressurized MDIs, patients need to inhale correctly and coordinate breathing and actuation to ensure effective drug delivery. For DPIs, patients may struggle to generate sufficient inspiratory capacity to overcome the internal resistance of the device to de-aggregate the powdered drug into fine particles small enough for lung deposition [2, 3].

The Global Initiative for Chronic Obstructive Lung Disease (GOLD) report recognize that markers (eg, symptoms and exacerbations), other than lung function impairment are associated with more severe disease [1]. Nebulized therapy may be an option in patients with more severe markers of COPD. Nebulized bronchodilators are recommended for patients with COPD who have very low inspiratory flow rates, physical, or mental impairments that preclude the use of inhalers, including elderly patients and patients with severe disease. They are also available to patients with COPD who prefer nebulized therapies $[2,4,5]$. 
Revefenacin inhalation solution is a once-daily long-acting muscarinic antagonist delivered by a standard jet nebulizer that was approved by the US Food and Drug Administration (FDA) for the maintenance treatment of patients with COPD [6]. The efficacy of revefenacin has been demonstrated in previous randomized, controlled, phase 3 trials in broad populations of patients with moderate to very severe COPD with or without concurrent long-acting $ß$ agonist (LABA). Revefenacin significantly improved lung function (trough forced expiratory volume in 1 second $\left[\mathrm{FEV}_{1}\right]$ and overall treatment effect $\mathrm{FEV}_{1}$ ) compared with placebo in two replicate 12-week studies [7]. Revefenacin treatment was shown to improve $\mathrm{FEV}_{1}$ and respiratory health outcomes in a 52-week study with results similar to tiotropium via HandiHaler ${ }^{\circledR}$ [8]. Revefenacin was well tolerated for 52 weeks and has a safety profile that supports its long-term use in patients with COPD [9]. In addition, revefenacin was not associated with adverse cardiovascular events [10, 11]. Therefore, it may provide a beneficial treatment option for patients with cardiovascular disease, one of the most common comorbidities among patients with COPD [12].

Identifying patient subgroups who are most likely to benefit from nebulized long-acting muscarinic antagonist (LAMA) treatment can help clinicians direct therapy to patients at high risk for COPD exacerbations. Here, in this post hoc subgroup analysis, we evaluated the efficacy, and health outcomes of revefenacin $175 \mu \mathrm{g}$ versus placebo, in patients with markers of more severe COPD who participated in the replicate, placebo-controlled, 12-week phase 3 trials (0126 and 0127). Some of the methods and results of this analysis were previously reported in the form of an abstract [13].

\section{Methods}

\section{Study design and conduct}

Studies 0126 (NCT02459080) and 0127 (NCT02512510) were replicate, 12-week, randomized, double-blind, placebocontrolled, multiple-dose, parallel-group, phase 3 trials, and the design and conduct were described previously [7]. The studies were approved conducted according to the principles of the International Council on Harmonisation of Technical Requirements for Pharmaceuticals for Human Use guideline for good clinical practice [14], and the code of ethics of the World Medical Association's Declaration of Helsinki [15]; written informed consent was obtained from all patients. The protocol was reviewed and approved by an institutional review board (Quorum Review IRB, Seattle, Washington).

\section{Patients}

Inclusion and exclusion criteria have been described previously [7]. Briefly, patients aged $\geq 40$ years with moderate to very severe COPD, a smoking history $\geq 10$ pack-years, post-ipratropium $\mathrm{FEV}_{1} /$ forced vital capacity ratio $<0.7$, and postipratropium $\mathrm{FEV}_{1}<80 \%$ of predicted normal and $>700 \mathrm{~mL}$ at screening were enrolled. Concomitant LABAs (with or without inhaled corticosteroids [ICS] ) was permitted in up to $40 \%$ of the study population to ensure robust assessments of concurrent therapies used by patients. Once the $40 \%$ cap was reached, new patients who entered screening required a 14-day washout of any LABA-containing therapy before the ipratropium reversibility test at screening. Patients taking ICS/LABA at enrollment were switched to receive ICS monotherapy at an equivalent dose for at least 14 days, before the ipratropium reversibility visit at screening. Stable doses of ICS without concomitant LABAs were permitted, but LAMAs and short-acting muscarinic antagonists were prohibited.

Patients were randomized $(1: 1: 1)$ in a double-blind manner to receive revefenacin $175 \mu \mathrm{g}$, revefenacin $88 \mu \mathrm{g}$, or placebo once daily via PARI LC ${ }^{\circledR}$ Sprint (Starnberg, Germany) jet nebulizer for 12 weeks. Results with revefenacin $175 \mathrm{mg}$, which is the FDA-approved dose, are reported here.

\section{Analysis population and endpoints}


Endpoints of this study included the least squares (LS) change from baseline in trough $\mathrm{FEV}_{1}$ at Day 85, St. George's Respiratory Questionnaire (SGRQ) responders, and transition dyspnea index (TDI) responders at Day 85. This analysis included the intention-to-treat (ITT) population and subgroups of patients at high risk for COPD exacerbations, and compared patients who received revefenacin $175 \mu \mathrm{g}$ and placebo. The following subgroups of patients were analyzed: severe airflow limitation (percent predicted $\mathrm{FEV}_{1} 30 \%-<50 \%$ ), very severe airflow limitation (percent predicted $\mathrm{FEV}_{1}$ $<30 \%$ ), 2011 GOLD D, patients that are reversible ( $\geq 12 \%$ and $\geq 200 \mathrm{~mL}$ increase in $\mathrm{FEV}_{1}$ ) to short-acting bronchodilators (ipratropium and albuterol), background ICS, background LABA and/or ICS, older age (defined as 65 or $>75$ years), and comorbidity risk factors which included history of cardiovascular disease, diabetes mellitus, and cognitive/mental impairments.

\section{Statistical analyses}

The full analysis set included all randomized patients who received at least one dose of study drug and had at least one recorded post-baseline $\mathrm{FEV}_{1}$ assessment. Pooled analyses were conducted using a repeated statement of subject ID nested within study instead of a random statement to ensure convergence. Changes from baseline in $\mathrm{FEV}_{1}$ were analyzed using a mixed model for repeated measures. Trough FEV 1 at Day 85 is defined as the mean of the 23.25-, and 23.75-hour spirometry assessments post the Day 84 dose. Trough FEV ${ }_{1}$ at Days 15, 29, 57, and 84 is defined as the mean of the -45 min and -15 min pre-dose spirometry assessments. SGRQ and TDI responders were the proportions of patients with a reduction in SGRQ total score $\geq 4$ units, or an increase in TDI score $\geq 1$ unit (ie, minimum clinically important differences [MCID]), respectively $[16,17]$.

\section{Results}

\section{Patient demographics and baseline characteristics}

Data from 812 patients were pooled for analysis, with 395 patients receiving revefenacin $175 \mu \mathrm{g}$, and 417 patients receiving placebo (Table 1). Across both treatment groups, approximately $45 \%$ of patients were $>65$ years, $10 \%$ were $>75$ years, and $37 \%$ were on background LABA and/or ICS. In addition, approximately $31 \%$ of patients had severe airflow limitation (percent predicted $\mathrm{FEV}_{1} 30 \%-<50 \%$ ), and 34\% met 2011 GOLD D criteria. For comorbidities, approximately $47 \%, 20 \%$, and $15 \%$ of patients had a history of cardiovascular disease, diabetes mellitus, and cognitive/mental impairments, respectively. Overall, patient demographics and baseline characteristics from the pooled analysis indicated that revefenacin and placebo groups were well balanced across all variables (Table 1).

\section{Changes from baseline in trough FEV 1}

Across the ITT population and subgroups, revefenacin $175 \mu \mathrm{g}$ produced significantly greater improvements in Day 85 trough $\mathrm{FEV}_{1}$ than placebo (Figure 1 and Table 2). Of note, revefenacin demonstrated significantly greater improvements in trough $\mathrm{FEV}_{1}$ among patients who are reversible to short-acting bronchodilators versus placebo (LS mean [95\% confidence intervals] difference, 286.52 [214.8, 358.2] $\mathrm{mL}, p<0.0001)$, In addition, revefenacin demonstrated significant increases in $\mathrm{FEV}_{1}$ among elderly patients (aged $>75$ years, and $>65$ years), providing additional $129-140 \mathrm{~mL}$ improvements versus placebo (both $p$-values $<0.03$ ). Among patients with comorbidities, revefenacin demonstrated significantly greater improvements in trough $\mathrm{FEV}_{1}$ among patients with a history of diabetes mellitus, cardiovascular disease, and cognitive/mental impairments, providing additional 102-150 mL improvements versus placebo (all pvalues $<0.03$ ) (Figure 1 and Table 2).

\section{SGRQ responders}


In the ITT population, a higher proportion of patients in the revefenacin $175 \mu \mathrm{g}$ arm (46.9\%) met the MCID criteria of SGRQ responder than placebo (36.2\%) (Figure 2 and Table 3), with the odds of response significantly greater in the revefenacin $175 \mu \mathrm{g}$ arm than in the placebo arm $(p=0.0116)$. In general, the majority of subgroup analyses showed a higher rate of responders for revefenacin than for placebo, with the odds of response (odds ratio >2.0) significantly greater in the revefenacin arm than in the placebo arm, among the severe $(p=0.037)$ and very severe $(p<0.001)$ airflow limitations, and 2011 GOLD D $(p=0.004)$ subgroups. In addition, the cardiovascular disease subgroup showed a nonsignificant trend, with the odds of response exceeding 2.0; odds ratio 2.3 (95\% confidence intervals $0.68-7.83, p=$ 0.1822) (Figure 2 and Table 3).

\section{TDI responders}

In the ITT population, a higher proportion of patients in the revefenacin arm (55.0\%) met the MCID criteria of TDI responder than placebo (47.2\%), with the odds of response greater in the revefenacin arm than in the placebo arm (Figure 3 and Table 4). Overall, the majority of subgroup analyses showed a higher rate of responders for revefenacin than for placebo, with the odds of response significantly greater among the severe airflow obstruction subgroup, odds ratio 2.37 (95\% confidence intervals 1.10-5.08,

$p=0.027$ ), and a tendency towards significance in the 2011 GOLD D subgroup, odds ratio 1.95 ( $95 \%$ confidence intervals 0.93-4.09, $p=0.079)$. In addition, the odds of being a TDI responder were significantly greater in the revefenacin arm than in the placebo among patients aged $>75$ years; odds ratio 4.7 (95\% confidence intervals $1.02-21.86, p=0.047$ )

(Figure 3 and Table 4).

\section{Discussion}

This post hoc subgroup analysis of two replicate, randomized, double-blind, placebo-controlled, parallel-group, 12-week phase 3 trials (0126 and 0127) provides evidence for the efficacy of revefenacin delivered by a standard jet nebulizer in patients with COPD that had markers of severe disease. This analysis of pooled data from Studies 0126 and 0127 in all subgroups of patients with COPD that had markers of severe disease, showed that revefenacin was associated with significant improvements in lung function (range, 102-176 mL), which was comparable with the ITT population (148 $\mathrm{mL})$.

In addition, revefenacin demonstrated improvements in health-related quality of life (as measured by SGRQ responders) and dyspnea (as measured by TDI responders) in the majority of patient subgroups versus placebo; these improvements were also comparable to those observed in the ITT population. The odds of being a SGRQ responder were significantly greater among patients with severe airflow obstruction (percent predicted $\mathrm{FEV}_{1} 30 \%-<50 \%$ ), very severe airflow obstruction (percent predicted $\mathrm{FEV}_{1}<30 \%$ ), and those classified as 2011 GOLD D. Among patients with comorbidities, the odds of response in the revefenacin group with a history of cardiovascular disease showed a non-significant trend (odds ratio $>2.0$ ) compared with placebo. It is likely significance was not met due to the relatively small patient numbers. The odds of being a TDI responder were significantly greater among patients with severe airflow obstruction (percent predicted $\mathrm{FEV}_{1} 30 \%-<50 \%$ ), and those aged $>75$ years, and there was a tendency towards significance in the $2011 \mathrm{GOLD}$ D subgroup.

Results of this analysis are consistent with other studies that evaluated the efficacy of patients taking revefenacin and a concomitant LABA or LABA/ICS, or combining other LAMAs with LABA or LABA/ICS. Revefenacin $175 \mu$ demonstrated improvements in $\mathrm{FEV}_{1}$ in concomitant LABA patients in a 52 week study [8]. The efficacy of combined LAMA/LABA treatments has been shown to improve lung function and health outcomes [18-20]. In a systematic review and metaanalysis, it was reported that combining LAMA with LABA and ICS in patients with advanced COPD have better lung 
function and health-related quality of life and lower rates of moderate/severe COPD exacerbations than dual therapy or monotherapy [21].

In this analysis, revefenacin resulted in significant improvements in lung function, SGRQ and TDI among patients with severe airflow obstruction (percent predicted $\mathrm{FEV}_{1} 30-<50 \%$ ) and classified as GOLD D in this study, which is consistent with previous studies. Nebulized glycopyrrolate was shown to improve FEV ${ }_{1}, \mathrm{SGRQ}$, and TDI in patients with moderate to very severe COPD [22]. Furthermore, tiotropium demonstrated higher efficacy versus salmeterol in prolonging time to first COPD exacerbation and reducing number of exacerbations in patients both at high exacerbation risk [18]. In addition, aclidinium $400 \mu \mathrm{g}$ significantly improved respiratory symptoms among patients who were classified as GOLD D at baseline [23].

Patients with COPD frequently have comorbid conditions, which can influence mortality and hospitalizations [1]. In this study, revefenacin demonstrated significant improvements in $\mathrm{FEV}_{1}$ and health outcomes among patient subgroups with cardiovascular disease, and diabetes mellitus compared with patients who received placebo. Similarly, nebulized glycopyrrolate improved $\mathrm{FEV}_{1}$, and patient-reported outcomes in patients with COPD, irrespective of cardiovascular risk status [24]. In previous studies of patients with COPD and comorbid type 2 diabetes, ICS therapy may have a negative impact on diabetes control, and patients prescribed higher doses may be at greater risk of diabetes progression [25, 26]. In the GOLD report, combination ICS/LABA or LAMA/LABA or LAMA monotherapy are recommended for GOLD D patients [1]. However, in patients with comorbid diabetes, it may be more appropriate to limit the use of ICS to the minority of patients with COPD who might benefit.

There were no safety issues identified with the use of revefenacin in patients with cardiac risk factors [7, 9]. In a preclinical study, revefenacin was shown to be a high-affinity competitive antagonist at human recombinant muscarinic acetylcholine receptors with kinetic functional selectivity for $\mathrm{M}_{3}$ over $\mathrm{M}_{2}$ muscarinic acetylcholine receptors [27]. In addition, revefenacin is a metabolically labile primary amide "soft-drug" site that allows rapid systemic clearance of the parent drug, thus potentially minimizing systemically mediated adverse events $[27,28]$.

Results of this analysis also demonstrated significant improvements in $\mathrm{FEV}_{1}$ in patients who received revefenacin among subgroups aged $>65$ years and $>75$ years, and cognitive/mental impairments, versus those who received placebo. Similarly, a retrospective analysis demonstrated the efficacy and safety of tiotropium among elderly patients with COPD ( $<70$ years, $70-79$ years, and $\geq 80$ years) [29]. Previous studies have suggested that nebulized therapy may be an appropriate option in patients with COPD and arthritis, impaired manual dexterity, chronic muscle weakness, or mental health or confusion disorders, or who are in hospitals, tertiary care centers, and assisted care settings as they may prefer nebulized therapy that is easy to use and does not require special training $[2,30]$.

Several limitations should be noted for this study. The treatment period was only three months, which does not allow for conclusions on long-term treatment. Due to small sample sizes in the subgroups and post hoc nature of this study, results should be interpreted with caution. The populations assessed in this study had stable COPD and did not include patients that had recent hospitalizations or respiratory infections. Peak inspiratory flow rate was not assessed at baseline, and therefore, patients with a suboptimal peak inspiratory flow rate could not be assessed as a potential population with markers of more severe COPD.

\section{Conclusions}

In summary, in this post hoc subgroup analysis of data from Studies 0126 and 0127 among patients with markers of more severe COPD, revefenacin treatment showed significant improvements in lung function. In addition, there was a greater number of SGRQ and TDI responders in the ITT population and the majority of patient subgroups among patients 
who received revefenacin versus placebo. Based on the data presented, revefenacin could be a therapeutic option among patients with markers of more severe COPD.

\section{Declarations}

\section{Ethics approval and consent to participate}

This study was conducted in accordance with the protocol, the principles of the International Council on Harmonisation of Technical Requirements for Registration of Pharmaceuticals for Human Use Guideline for Good Clinical Practice, the United States Code of Federal Regulations, the principles of the World Medical Association Declaration of Helsinki, Ethical Principles for Medical Research Involving Human Subjects, and all applicable regulatory requirements. The protocol was reviewed and approved by an institutional review board (Quorum Review IRB, Seattle, Washington).

\section{Consent for publication}

Not applicable.

\section{Availability of data and materials}

Theravance Biopharma (and its affiliates) will not be sharing individual de-identified participant data or other relevant study documents. Theravance Biopharma reviews the appropriateness of public disclosure of de-identified study data on a regular basis; however, at this time, has determined that public disclosure is not appropriate for advancing the knowledge around COPD treatment.

\section{Competing interests}

JFD is a consultant and advisory committee member for Mylan Inc. and Sunovion Pharmaceuticals.

EK has participated in consulting, advisory boards, speaker panels, or received travel reimbursement for Amphastar, AstraZeneca, Boehringer Ingelheim, GlaxoSmithKline, Mylan, Novartis, Oriel, Pearl, Sunovion, Teva and Theravance Biopharma US, Inc. He has conducted multicenter clinical research trials for approximately 40 pharmaceutical companies.

CNB was an employee of Theravance Biopharma US, Inc. at the time this study was conducted.

EJM, BH, and GDC are current employees of Theravance Biopharma US, Inc.

\section{Funding}

This study was funded by Theravance Biopharma Ireland Limited (Dublin, Ireland). Mylan, Inc. (Canonsburg, Pennsylvania) and Theravance Biopharma US, Inc. (South San Francisco, California) funded medical writing support.

Theravance Biopharma Ireland Limited (Dublin, Ireland) contributed to the design of the study, data collection, analysis, and interpretation of data.

Theravance Biopharma US, Inc. (South San Francisco, California) contributed to the analysis and interpretation of data. Theravance Biopharma US, Inc. (South San Francisco, California) employees/authors contributed to the writing of the manuscript.

Mylan, Inc. (Canonsburg, Pennsylvania) contributed to the design of the study and interpretation of data.

\section{Authors' contributions}

Page $7 / 21$ 
JFD, EK, CNB, EJM, BH, and GDC take responsibility for the conception and design.

JFD, EK, CNB, EJM, BH, and GDC take responsibility for data analysis and interpretation.

JFD, EK, CNB, EJM, BH, and GDC take responsibility for drafting the manuscript for important intellectual content.

All authors approve the submitted version of the manuscript and agree to be accountable for the accuracy and integrity of the work.

\section{Acknowledgments}

The authors acknowledge Gráinne Faherty, MPharm, for medical writing and Frederique H. Evans, MBS, for editorial assistance in the preparation of the manuscript (Ashfield Healthcare Communications, Middletown, CT, USA).

\section{Abbreviations}

COPD: Chronic obstructive pulmonary disease; DPI: Dry powder inhaler; FDA: Food and Drug Administration; FEV 1 : Forced expiratory volume in 1 second; GOLD: Global Initiative for Chronic Obstructive Lung Disease; ICS: Inhaled corticosteroid; ITT: Intention-to-treat; LABA: Long-acting ß agonist; LAMA: Long-acting muscarinic antagonist; MDI: Metered-dose inhaler; SGRQ: St. George's Respiratory Questionnaire; TDI: Transition dyspnea index.

\section{References}

1. Global Initiative for Chronic Obstructive Lung Disease. Global strategy for the diagnosis, management, and prevention of chronic obstructive pulmonary disease (2019 report). https://goldcopd.org/wpcontent/uploads/2018/11/GOLD-2019-POCKET-GUIDE-DRAFT-v1.7-14Nov2018-WMS.pdf. Accessed 10 November 2019.

2. Tashkin D. A review of nebulized drug delivery in COPD. Int J Chron Obstruct Pulmon Dis. 2016;11:2585-96.

3. Muralidharan P, Hayes Jr D, Mansour H. Dry powder inhalers in COPD, lung inflammation and pulmonary infections. Expert Opin Drug Deliv. 2015;12:947-62.

4. Dhand R, Dolovich M, Chipps B, Myers T, Restrepo R, Farrar J. The role of nebulized therapy in the management of COPD: evidence and recommendations. COPD. 2012;9:58-72.

5. Jarvis S, Ind P, Shiner R. Inhaled therapy in elderly COPD patients; time for re-evaluation? Age Ageing. 2007;36:213218.

6. US Food and Drug Administration. HIGHLIGHTS OF PRESCRIBING INFORMATION YUPELRI ${ }^{\circledR}$ (revefenacin) inhalation solution, for oral inhalation. 2018.

https://www.accessdata.fda.gov/drugsatfda_docs/label/2018/210598s000lbl.pdf. Accessed 10 November 2019.

7. Ferguson G, Feldman G, Pudi K, Barnes C, Moran E, Haumann B, et al. Improvements in lung function with nebulized revefenacin in the treatment of patients with moderate to very severe COPD: results from two replicate phase III clinical trials Chronic Obstr Pulm Dis. 2019;6:154-65.

8. Donohue J, Kerwin E, Sethi S, Haumann B, Pendyala S, Dean L, et al. Maintained therapeutic effect of revefenacin over 52 weeks in moderate to very severe chronic obstructive pulmonary disease (COPD). Respir Res 2019;20(1):241.

9. Donohue J, Kerwin E, Sethi S, Haumann B, Pendyala S, Dean L, et al. Revefenacin, a once-daily, lung-selective, longacting muscarinic antagonist for nebulized Therapy: safety and tolerability results of a 52-week phase 3 trial in moderate to very severe chronic obstructive pulmonary disease. Respir Med 2019;153:38-43. 
10. Borin M, Barnes C, Darpo B, Pendyala S, Xue H, Bourdet D. Revefenacin, a long-acting muscarinic antagonist, does not prolong QT interval in healthy subjects: results of a placebo- and positive-controlled thorough QT study. Clin Pharmacol Drug Dev. https://accp1.onlinelibrary.wiley.com/doi/full/10.1002/cpdd.732. Accessed 10 November 2019.

11. Donohue J, Feldman G, Sethi S, Barnes C, Pendyala S, Bourdet D, et al. Cardiovascular safety of revefenacin, a oncedaily, lung-selective, long-acting muscarinic antagonist for nebulized therapy of chronic obstructive pulmonary disease. Pulm Pharmacol Ther. 2019;101808.

12. Mannino D, Thorn D, Swensen A, Holguin F. Prevalence and outcomes of diabetes, hypertension and cardiovascular disease in COPD. Eur Respir J. 2008;32:962-9.

13. Donohue J, Kerwin E, Barnes C, Moran E, Haumann B, Pendyala S, et al. Efficacy of revefenacin, a long-acting muscarinic antagonist for nebulized therapy in chronic obstructive pulmonary disease patients with markers of more severe disease. Chest. 2018;154:736A-737A.

14. International Council for Harmonisation of Technical Requirements for Pharmaceuticals for Human Use (ICH). Integrated addendum to ICH E6(rR1): guideline for good clinical practice E6 (R2). 2015. http://www.ich.org/fileadmin/Public_Web_Site/ICH_Products/Guidelines/Efficacy/E6/E6_R2_Addendum_Step2.pdf. Accessed 10 November 2019.

15. World Medical Association. World Medical Association Declaration of Helsinki: ethical principles for medical research involving human subjects. JAMA. 2013;310:2191-4.

16. Jones P. St. George's respiratory questionnaire: MCID. COPD. 2005;2:75-9.

17. Mahler D, Witek T. The MCID of the transition dyspnea index is a total score of one unit. COPD. 2005;2:99-103.

18. Vogelmeier C, Asijee G, Kupas K, Beeh K. Tiotropium and salmeterol in COPD Patients at risk of exacerbations: A post hoc analysis from POET-COPD ${ }^{\circledR}$. Adv Ther. 2015;32:537-47.

19. Vogelmeier C, Paggiaro P, Dorca J, Sliwinski P, Mallet M, Kirsten A, et al. Efficacy and safety of aclidinium/formoterol versus salmeterol/fluticasone: a phase 3 COPD study. Eur Respir J. 2016;48:1030-9.

20. Wedzicha J, Banerji D, Chapman K, Vestbo J, Roche N, Ayers R, et al. Indacaterol-Glycopyrronium versus SalmeterolFluticasone for COPD. N Engl J Med. 2016;374:2222-34.

21. Zheng Y, Zhu J, Liu Y, Lai W, Lin C, Qiu K, et al. Triple therapy in the management of chronic obstructive pulmonary disease: systematic review and meta-analysis. BMJ. 2018;363:k4388.

22. Kerwin E, Donohue J, Goodin T, Tosiello R, Wheeler A, Ferguson G. Efficacy and safety of glycopyrrolate/eFlow ${ }^{\circledR}$ CS (nebulized glycopyrrolate) in moderate-to-very-severe COPD: Results from the glycopyrrolate for obstructive lung disease via electronic nebulizer (GOLDEN) 3 and 4 randomized controlled trials. Respir Med. 2017;132:238-50.

23. Wedzicha J, Agusti A, Donaldson G, Chuecos F, Lamarca R, Garcia Gil E. Effect of aclidinium bromide on exacerbations in patients with moderate-to-severe COPD: a pooled analysis of five phase III, randomized, placebocontrolled studies. COPD. 2016;13:669-76.

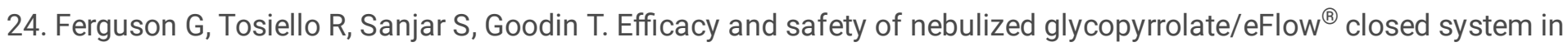
patients with moderate-to-very-severe chronic obstructive pulmonary disease with pre-existing cardiovascular risk factors. Chronic Obstr Pulm Dis. 2018;6:86-99.

25. Herth F, Bramlage P, Müller-Wieland D. Current perspectives on the contribution of inhaled corticosteroids to an increased risk for diabetes onset and progression in patients with chronic obstructive pulmonary disease. Respiration. 2015;89:66-75.

26. Price D, Russell R, Mares R, Burden A, Skinner D, Mikkelsen H, et al. Metabolic effects associated with ICS in patients with COPD and comorbid Type 2 Diabetes: a historical matched cohort study. PLoS One. 2016;11:e0162903. 
27. Quinn D, Barnes C, Yates W, Bourdet D, Moran E, Potgieter P, et al. Pharmacodynamics, pharmacokinetics and safety of revefenacin (TD-4208), a long-acting muscarinic antagonist, in patients with chronic obstructive pulmonary disease (COPD): Results of two randomized, double-blind, phase 2 studies. Pulm Pharmacol Ther. 2018;48:71-9.

28. Ji Y, Husfeld C, Pulido-Rios M, Mcnamara A, Obedencio G, Baldwin M, et al. Duration by design: discovery of revefenacin, the first-in-class nebulized once-daily bronchodilator for the treatment of patients with COPD. Chest. 2016;150.

29. Satoh H, Kagohashi K, Ohara G, Sato S, Miyazaki K, Nakazawa K, et al. Use of tiotropium in patients with COPD aged 80 years and older. Exp Ther Med. 2013;5:997-1000.

30. Dolovich M, Ahrens R, Hess D, Anderson P, Dhand R, Rau J, et al. Device selection and outcomes of aerosol therapy: Evidence-based guidelines: American College of Chest Physicians/American College of Asthma, Allergy, and Immunology. Chest. 2005;127:335-71.

\section{Tables}

Table 1. Pooled population demographics and baseline characteristics

\begin{tabular}{|l|c|c|}
\hline Characteristic & $\begin{array}{c}\text { Revefenacin 175 } \mathrm{ug} \\
(\mathrm{n}=395)\end{array}$ & $\begin{array}{c}\text { Placebo } \\
(\mathrm{n}=417)\end{array}$ \\
\hline Sex, male, n (\%) & $195(49.4)$ & $206(49.4)$ \\
\hline$>65$ years, n (\%) & $176(44.6)$ & $185(44.4)$ \\
\hline$>75$ years, n (\%) & $35(8.9)$ & $42(10.1)$ \\
\hline Current smoker, n (\%) & $190(48.1)$ & $198(47.5)$ \\
\hline Concurrent LABA or ICS/LABA, n (\%) & $153(38.7)$ & $147(35.3)$ \\
\hline Concurrent ICS, n (\%) & $174(44.1)$ & $171(41.0)$ \\
\hline FEV $130 \%-<50 \%$ pred, n (\%) & $119(30.1)$ & $134(32.1)$ \\
\hline FEV $1<30 \%$ pred, n (\%) & $26(6.6)$ & $16(3.8)$ \\
\hline 2011 GOLD category D, n (\%) & $132(33.4)$ & $141(33.8)$ \\
\hline Reversible to ipratropium and albuterol, $\mathrm{n}(\%)$ & $86(21.8)$ & $82(19.7)$ \\
\hline History of cardiovascular disease ${ }^{\mathrm{a}}$ & $178(45.1)$ & $200(48.0)$ \\
\hline History of diabetes & $80(20.3)$ & $78(18.7)$ \\
\hline History of cognitive/mental impairments & $58(14.7)$ & $61(14.6)$ \\
\hline
\end{tabular}

${ }^{\mathrm{a}}$ Cardiovascular risk factors: aged $\geq 60$ years and any two of the following conditions: diabetes, hypercholesterolemia, hypertension, peripheral vascular disorder or cardiac disorders from reported medical history or aged $\geq 40$ years and a cardiac disorder(s) from reported medical history.

$\mathrm{FEV}_{1}=$ forced expiratory volume in 1 second; GOLD = Global Initiative for Chronic Obstructive Lung Disease; ICS = inhaled corticosteroids; LABA = long-acting $§$ agonist. 
Table 2. Day 85 trough FEV 1 (mL) by patient subgroup 


\begin{tabular}{|c|c|c|}
\hline Subgroups & $\begin{array}{l}\text { Revefenacin } 175 \mu \mathrm{g} \\
\qquad(\mathrm{n}=395)\end{array}$ & $\begin{array}{l}\text { Placebo } \\
(n=417)\end{array}$ \\
\hline \multicolumn{3}{|l|}{ ITT } \\
\hline Evaluable $\mathrm{n}$ & 310 & 296 \\
\hline LS mean difference (95\% CI) & $148.1(115.2,181.1) ; p<0.0001$ & \\
\hline \multicolumn{3}{|l|}{$\mathrm{FEV}_{1} 30 \%-<50 \%$ pred } \\
\hline Evaluable $\mathrm{n}$ & 101 & 78 \\
\hline LS mean difference (95\% CI) & $131.2(70.7,191.6), p<0.0001$ & \\
\hline \multicolumn{3}{|l|}{$\mathrm{FEV}_{1}<30 \%$ pred } \\
\hline Evaluable $\mathrm{n}$ & 17 & 9 \\
\hline LS mean difference (95\% CI) & $176.2(14.7,337.5), p=0.0324$ & \\
\hline \multicolumn{3}{|l|}{2011 GOLD category D } \\
\hline Evaluable $\mathrm{n}$ & 108 & 83 \\
\hline LS mean difference $(95 \% \mathrm{CI})$ & $124.6(66.5,182.7), p<0.0001$ & \\
\hline \multicolumn{3}{|l|}{ ICS use } \\
\hline Evaluable n & 135 & 108 \\
\hline LS mean difference (95\% CI) & $130.6(78.7,182.5), p<0.001$ & \\
\hline \multicolumn{3}{|l|}{ LABA or ICS/LABA use } \\
\hline Evaluable n & 118 & 89 \\
\hline LS mean difference (95\% CI) & $139.2(82.9,195.5), p<0.0001$ & \\
\hline \multicolumn{3}{|l|}{$>65$ years } \\
\hline Evaluable $\mathrm{n}$ & 143 & 128 \\
\hline LS mean difference (95\% CI) & $140.3(91.0,189.7), p<0.0001$ & \\
\hline \multicolumn{3}{|l|}{$>75$ years } \\
\hline Evaluable $\mathrm{n}$ & 28 & 25 \\
\hline LS mean difference (95\% CI) & $129.2(18.9,239.5), p=0.0217$ & \\
\hline \multicolumn{3}{|c|}{ Reversible to ipratropium and albuterol } \\
\hline Evaluable $\mathrm{n}$ & 70 & 57 \\
\hline
\end{tabular}




\begin{tabular}{|c|c|c|}
\hline LS mean difference $(95 \% \mathrm{CI})$ & $286.5(214.8,358.2), p<0.0001$ & \\
\hline \multicolumn{3}{|l|}{ History of CV disease } \\
\hline Evaluable $\mathrm{N}$ & 21 & 27 \\
\hline LS mean difference (95\% CI) & $140.7(18.4,263.0), p=0.0242$ & \\
\hline \multicolumn{3}{|l|}{ History of diabetes } \\
\hline Evaluable N & 85 & 57 \\
\hline LS mean difference (95\% CI) & $101.6(27.0,176.3), p=0.0077$ & \\
\hline \multicolumn{3}{|c|}{ History of cognitive/mental impairments } \\
\hline Evaluable N & 45 & 44 \\
\hline LS mean difference $(95 \% \mathrm{CI})$ & $149.5(64.5,234.5), p=0.0006$ & \\
\hline
\end{tabular}

$\mathrm{CI}=$ confidence intervals $; \mathrm{CV}=$ cardiovascular; $\mathrm{FEV}_{1}=$ forced expiratory volume in 1 second; GOLD = Global Initiative for Chronic Obstructive Lung Disease, LABA = long-acting $ß$ agonist; ICS = inhaled corticosteroids; ITT = intention-to-treat; pred = predicted.

Table 3. Day 85 SGRQ responders by patient subgroup 


\begin{tabular}{|c|c|c|}
\hline Subgroups & $\begin{array}{l}\text { Revefenacin } 175 \mu \mathrm{g} \\
\qquad(\mathrm{n}=395)\end{array}$ & $\begin{array}{l}\text { Placebo } \\
(\mathrm{n}=417)\end{array}$ \\
\hline \multicolumn{3}{|l|}{ ITT } \\
\hline Evaluable $\mathrm{n}$ & 288 & 276 \\
\hline Odds ratio $(95 \% \mathrm{CI})$ & $1.53(1.10,2.13), p=0.0116$ & \\
\hline \multicolumn{3}{|l|}{$\mathrm{FEV}_{1} 30 \%-<50 \%$ pred } \\
\hline Evaluable $\mathrm{n}$ & 96 & 78 \\
\hline Odds ratio $(95 \% \mathrm{CI})$ & $1.99(1.04,3.81), p=0.0368$ & \\
\hline \multicolumn{3}{|l|}{$\mathrm{FEV}_{1}<30 \%$ pred } \\
\hline Evaluable n & 16 & 7 \\
\hline Odds ratio $(95 \% \mathrm{CI})$ & $\begin{array}{c}2 \times 10^{10}\left(3.05 \times 10^{7}, 126 \times 10^{9}\right) \\
p<0.001\end{array}$ & \\
\hline \multicolumn{3}{|l|}{2011 GOLD category D } \\
\hline Evaluable $\mathrm{n}$ & 103 & 81 \\
\hline Odds ratio $(95 \% \mathrm{CI})$ & $2.52(1.34,4.76), p=0.0042$ & \\
\hline \multicolumn{3}{|l|}{ ICS use } \\
\hline Evaluable $\mathrm{n}$ & 134 & 105 \\
\hline Odds ratio $(95 \% \mathrm{CI})$ & $1.23(0.74,2.03), p=0.4291$ & \\
\hline \multicolumn{3}{|l|}{ LABA or ICS/LABA use } \\
\hline Evaluable n & 118 & 85 \\
\hline Odds ratio $(95 \% \mathrm{CI})$ & $1.34(0.77,2.35), p=0.2995$ & \\
\hline \multicolumn{3}{|l|}{$>65$ years } \\
\hline Evaluable $\mathrm{n}$ & 133 & 119 \\
\hline Odds ratio $(95 \% \mathrm{CI})$ & $1.11(0.67,1.84), p=0.6897$ & \\
\hline \multicolumn{3}{|l|}{$>75$ years } \\
\hline Evaluable $\mathrm{n}$ & 28 & 25 \\
\hline Odds ratio $(95 \% \mathrm{CI})$ & $0.58(0.19,1.81), p=0.3506$ & \\
\hline Reversible to ipratropiur & & \\
\hline
\end{tabular}




\begin{tabular}{|c|c|c|}
\hline Evaluable $\mathrm{n}$ & 66 & 51 \\
\hline Odds ratio $(95 \%$ CI) & $1.12(0.55,2.30), p=0.7486$ & \\
\hline \multicolumn{3}{|l|}{ History of CV disease } \\
\hline Evaluable N & 19 & 25 \\
\hline Odds ratio $(95 \% \mathrm{CI})$ & $2.30(0.68,7.83), p=0.1822$ & \\
\hline \multicolumn{3}{|l|}{ History of diabetes } \\
\hline Evaluable N & 60 & 53 \\
\hline Odds ratio $(95 \% \mathrm{CI})$ & $1.31(0.63,2.75), p=0.4704$ & \\
\hline \multicolumn{3}{|c|}{ History of cognitive/mental impairments } \\
\hline Evaluable N & 43 & 40 \\
\hline Odds ratio $(95 \% \mathrm{CI})$ & $1.18(0.49,2.88), p=0.7126$ & \\
\hline
\end{tabular}

$\mathrm{CI}=$ confidence intervals; $\mathrm{CV}=$ cardiovascular; $\mathrm{FEV}_{1}=$ forced expiratory volume in 1 second; GOLD = Global Initiative for Chronic Obstructive Lung Disease, LABA = long-acting $ß$ agonist; ICS = inhaled corticosteroids; ITT = intention-to-treat; pred = predicted. 
Table 4. Day 85 TDI responders by patient subgroup 


\begin{tabular}{|c|c|c|}
\hline Subgroups & $\begin{array}{l}\text { Revefenacin } 175 \mu \mathrm{g} \\
\qquad(\mathrm{n}=395)\end{array}$ & $\begin{array}{l}\text { Placebo } \\
(\mathrm{n}=417)\end{array}$ \\
\hline \multicolumn{3}{|l|}{ ITT } \\
\hline Evaluable $\mathrm{n}$ & 280 & 271 \\
\hline Odds ratio $(95 \% \mathrm{CI})$ & $1.46(0.96,2.22), p=0.0760$ & \\
\hline \multicolumn{3}{|l|}{$\mathrm{FEV}_{1} 30 \%-<50 \%$ pred } \\
\hline Evaluable $\mathrm{n}$ & 95 & 77 \\
\hline Odds ratio $(95 \% \mathrm{CI})$ & $2.37(1.10,5.08), p=0.0268$ & \\
\hline \multicolumn{3}{|l|}{$\mathrm{FEV}_{1}<30 \%$ pred } \\
\hline Evaluable $\mathrm{n}$ & 15 & 7 \\
\hline Odds ratio $(95 \% \mathrm{CI})$ & $0.31(0.03,2.88), p=0.3016$ & \\
\hline \multicolumn{3}{|l|}{2011 GOLD category D } \\
\hline Evaluable $\mathrm{n}$ & 101 & 80 \\
\hline Odds ratio $(95 \% \mathrm{CI})$ & $1.95(0.93,4.09), p=0.0789$ & \\
\hline \multicolumn{3}{|l|}{ ICS use } \\
\hline Evaluable $\mathrm{n}$ & 131 & 100 \\
\hline Odds ratio $(95 \% \mathrm{CI})$ & $1.04(0.54,1.98), p=0.9115$ & \\
\hline \multicolumn{3}{|l|}{ LABA or ICS/LABA use } \\
\hline Evaluable $\mathrm{n}$ & 116 & 81 \\
\hline Odds ratio $(95 \% \mathrm{CI})$ & $1.16(0.57,2.35), p=0.6845$ & \\
\hline \multicolumn{3}{|l|}{$>65$ years } \\
\hline Evaluable $\mathrm{n}$ & 131 & 115 \\
\hline Odds ratio $(95 \% \mathrm{CI})$ & $1.43(0.76,2.68), p=0.2687$ & \\
\hline \multicolumn{3}{|l|}{$>75$ years } \\
\hline Evaluable $\mathrm{n}$ & 28 & 25 \\
\hline Odds ratio $(95 \% \mathrm{CI})$ & $4.72 \quad(1.02,21.86), p=0.0470$ & \\
\hline \multicolumn{3}{|c|}{ Reversible to ipratropium and albuterol } \\
\hline Evaluable $\mathrm{n}$ & 63 & 50 \\
\hline
\end{tabular}




\begin{tabular}{|l|c|c|} 
Odds ratio (95\% CI) & $1.72(0.67,4.38), p=0.2583$ & \\
History of CV disease & 18 & 25 \\
$\quad$ Evaluable N & $1.62(0.93,2.22), p=0.5397$ & \\
Odds ratio (95\% CI) & 61 & \\
History of diabetes & $1.41(0.55,3.64), p=0.4719$ & \\
$\quad \begin{array}{r}\text { Evaluable N } \\
\text { Odds ratio (95\% CI) }\end{array}$ & 41 \\
History of cognitive/mental impairments & $1.03(0.34,3.10), p=0.9552$ & \\
$\quad \begin{array}{l}\text { Evaluable N } \\
\text { Odds ratio (95\% CI) }\end{array}$ & \\
\hline
\end{tabular}

$\mathrm{CI}=$ confidence intervals; $\mathrm{CV}=$ cardiovascular; $\mathrm{FEV}_{1}=$ forced expiratory volume in 1 second; $\mathrm{GOLD}=$ Global Initiative for Chronic Obstructive Lung Disease, LABA = long-acting $ß$ agonist; ICS = inhaled corticosteroids; ITT = intention-to-treat; pred = predicted.

\section{Figures}




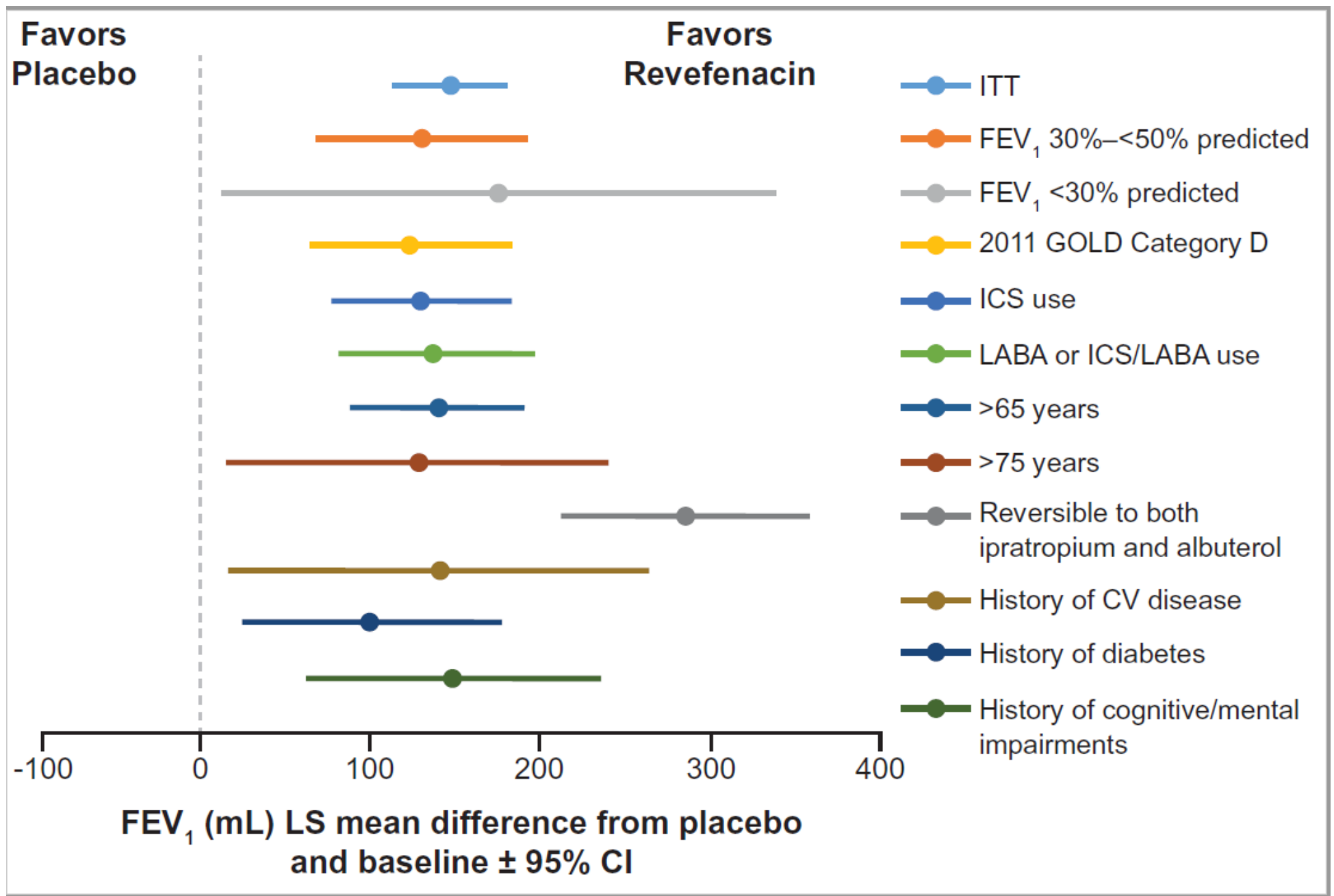

Figure 1

Day 85 trough FEV1 by patient subgroup The LS mean difference for revefenacin versus placebo was statistically significant $(p<0.05)$ for all subgroups. $\mathrm{Cl}=$ confidence intervals; $\mathrm{CV}$ = cardiovascular; FEV1 = forced expiratory volume in 1 second; GOLD = Global Initiative for Chronic Obstructive Lung Disease; LABA = long-acting $ß$ agonist; ICS = inhaled corticosteroids; ITT = intention-to-treat. 


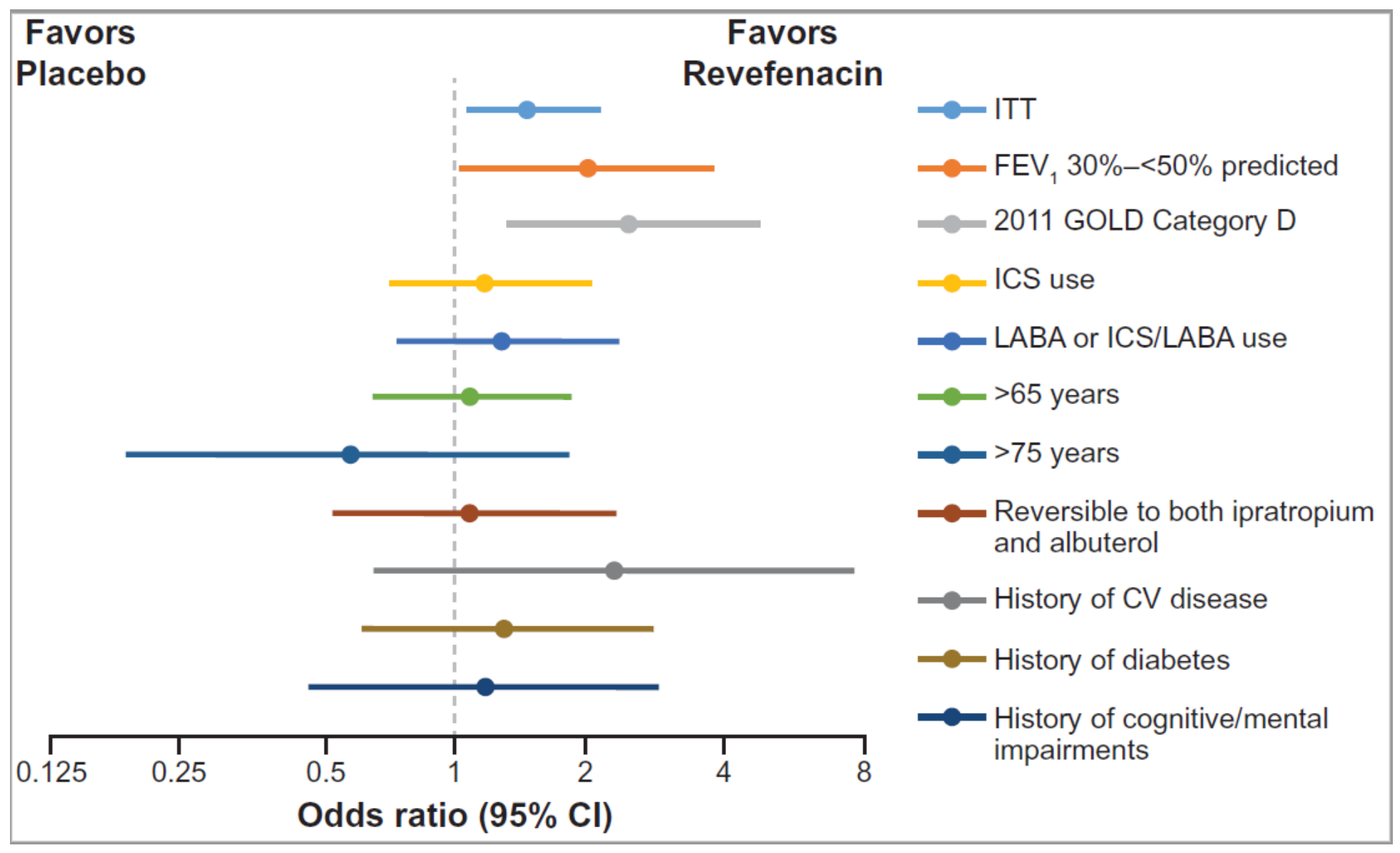

Figure 2

Day 85 SGRQ responders by patient subgroup The odds ratios for revefenacin versus placebo was statistically significant $(p<0.05)$ for the following subgroups: ITT, FEV1 30\%-<50\% predicted and, 2011 GOLD category D. The subgroup, FEV1 $<30 \%$ predicted, has been excluded from the forest plot due to being out with the range of the $x$-axis scale. $\mathrm{Cl}$ = confidence intervals; $\mathrm{CV}$ = cardiovascular; FEV1 = forced expiratory volume in 1 second; GOLD = Global Initiative for Chronic Obstructive Lung Disease; LABA = long-acting $ß$ agonist; ICS = inhaled corticosteroids; ITT = intention-to-treat; SGRQ, St. George's Respiratory Questionnaire. 


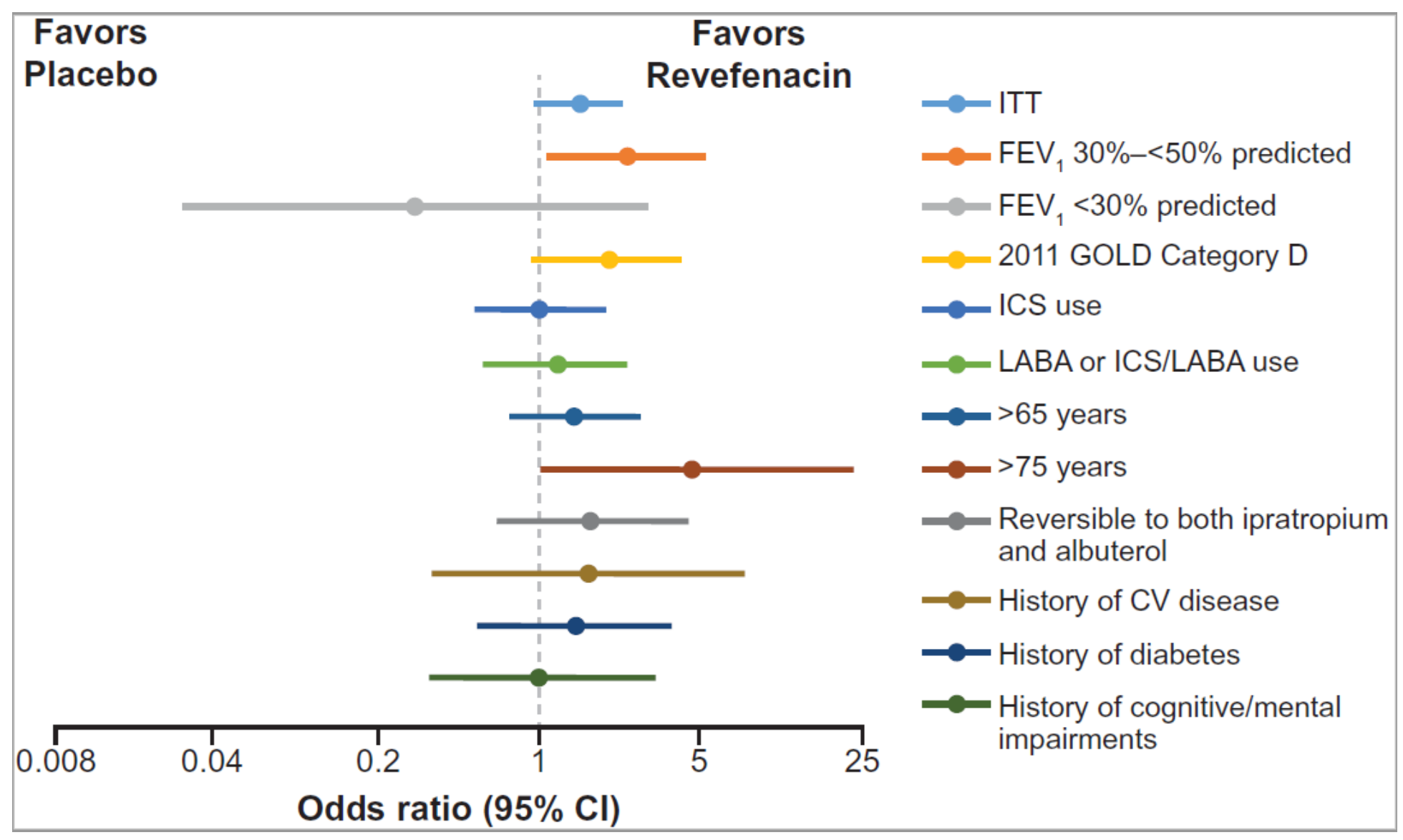

Figure 3

Day 85 TDI responders by patient subgroup The odds ratios for revefenacin versus placebo was statistically significant $(p<0.05)$ for the following subgroups: FEV1 30\%-<50\% predicted, and $>75$ years. $\mathrm{Cl}=$ confidence intervals; $\mathrm{CV}=$ cardiovascular; FEV1 = forced expiratory volume in 1 second; GOLD = Global Initiative for Chronic Obstructive Lung Disease; $L A B A$ = long-acting $ß$ agonist; ICS = inhaled corticosteroids; ITT = intention-to-treat; TDI = transition dyspnea index. 